https://nv.nltu.edu.ua

https://doi.org/10.36930/40300202

$@ \bowtie$ Correspondence author

Article received 03.04.2020 p.

Article accepted 04.06.2020 p.

S. A. Maslovata

UDC 712.4-025(477.4)

Г. П. Леонтяк' ${ }^{1}$ М. Ю. Осіпов², С. А. Масловата ${ }^{2}$ Ю. В. Майборода ${ }^{2}$

${ }^{I}$ Вінницький національний аграрний університет, м. Вінниия, Україна

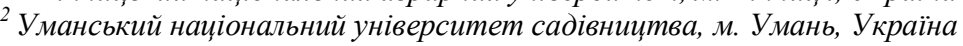

\title{
ПРОЕКТ БЛАГОУСТРОЮ ТА ОЗЕЛЕНЕННЯ ПРИСАДИБНОЇ ДІЛЯНКИ В МІСТІ УМАНЬ
}

\begin{abstract}
У містобудуванні озеленення є складовою частиною загального комплексу заходів щодо планування, забудови і впорядкування населених місць. Зелені насадження є основними елементами художнього оздоблення населених пунктів, естетичне та емоційне значення яких зумовлене можливістю з їхньою допомогою чергувати враження від навколишнього простору, вводити в урбанізоване середовище природні елементи. У процесі передпроєктних досліджень встановлено, що ділянка має прямокутну форму та рівнинний рельєф, прокладену дорожньо-стежкову мережу, бесідку, водойму, будинок, гараж і санву-

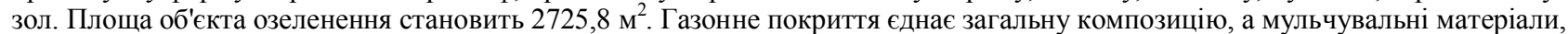
зокрема кора $\left(289,9 \mathrm{~m}^{2}\right)$ та гравій $\left(161,6\right.$ м $\left.^{2}\right)$, підкреслюють і виділяють рослинні композиції. Житлова зона - житловий будинок площею 180,9 м² 3 доріжками, що з'єднують та забезпечують доступний прохід. Цю зону поділено на дві частини: передню, що веде до партерної частини та задню - для з'єднання із зоною відпочинку. До будинку та навколо нього розміщується плиткова дорожньо-стежкова мережа, загальною площею 798,3 м², прокладена до кожної із наведених зон. Зону відпочинку відповідно поділено на: прогулянкову зону, садову зону, з водяних рослин, зону барбекю, садову зону. Дорожньо-стежкова мережа й архітектурне рішення спрямовані на проектування ділянки у регулярному стилі. Створення садово-паркового об'єкта із врахуванням особливостей природно-кліматичних умов, побажань замовника та функціонального зонування надасть території завершеного вигляду та слугуватиме місцем для відпочинку усієї родини. На ділянці не проглядається загальний задум, тому пропонуємо розмістити наведені рослини відповідно до їх функціональних зон. Таким способом вдасться раціонально використати загальну площу з уже прокладеною дорожньо-стежковою мережею та створити зручне зонування для експлуатації всієї території. Рослини підібрані так, щоб додати унікальності цьому об'єкту, підкреслити кожну запропоновану зону, але водночас зберегти цілісність загальної задумки та композиції всього об'єкта. Декоративність кожної рослини підкреслюється сезонно, тому мешканці цієї ділянки зможуть милуватися композиціями в будь-яку пору року. Вся територія з композиціями гарно освітлюється, чим підкреслюється фактура рослин та їх форми.
\end{abstract}

Ключові слова: ландшафтний дизайн; генеральний план; функціональне зонування території; житлова зона; зона відпочинку.

Вступ. У містобудуванні озеленення є складовою частиною загального комплексу заходів щодо планування, забудови і впорядкування населених місць. Озеленення має позитивний вплив на навколишнє середовище та життя населення загалом. Зелені насадження $\epsilon$ основними елементами художнього оздоблення населених пунктів, естетичне та емоційне значення яких зумовлене можливістю 3 їхньою допомогою чергувати враження від навколишнього простору, вводити в урбанізоване середовище природні елементи $[1,3,4]$.

Важливим компонентом системи озеленення $є$ насадження на житлових територіях, що створюють сприятливі умови для праці та відпочинку. Велике значення має принцип раціональності у розміщенні на ділянці дерев, кущів, квітників, правильний їх вибір відповідно до природних умов, а також догляд за садом та іншими

зеленими насадженнями. За вдалого розташування та якісного догляду у поєднанні з ефективною ландшафтною організацією території, зелені насадження зумовлюють екологічне становище населених місць, оскільки переважно від них залежить мікроклімат і природне очищення повітря, води і грунту $[2,5]$.

Актуальність дослідження полягає в тому, що зелені насадження відіграють важливу роль у формуванні середовища присадибної ділянки, надають індивідуальні, своєрідні риси. Максимальне використання природних матеріалів, а також водойм та наявної рослинності сприяє створенню високохудожніх садово-паркових композицій. Вибір планувального прийому залежить від призначення об'єкта та природних особливостей місцевості.

Об'єктом дослідження є благоустрій та озеленення

\section{Інформація про авторів:}

Леонтяк Григорій Прокопович, д-р с.-г. наук, професор, кафедра садово-паркового господарства, садівництва та виноградарства. Email: karmelukove_podilla@ukr.net

Осіпов Михайло Юрійович, канд. с.-г. наук, доцент, кафедри садово-паркового господарства. Email: m3dsad@gmail.com; https://orcid.org/0000-0001-7004-1164

Масловата Світлана Андріївна, канд. с.-г. наук, ст. викладач, кафедра лісового господарства. Email: svetlana_maslovataya@meta.ua; https://orcid.org/0000-0002-5725-0604

Майборода Юлія Володимирівна, магістрант, кафедра садово-паркового господарства. Email: painterjuliamaiboroda@gmail.com

Цитування за Дсту: Леонтяк Г. П., Осіпов М. Ю., Масловата С. А., Майборода Ю. В. Проект благоустрою та озеленення присадибної ділянки в місті Умань. Науковий вісник НЛТУ України. 2020, т. 30, № 2. С. 14-18.

Citation APA: Leontiak, G. P., Osipov, M. Yu., Maslovata, S. A., \& Mauboroda, Yu. V. (2020). Landscaping and improvement project for a garden plot in the city of Uman. Scientific Bulletin of UNFU, 30(2), 14-18. https://doi.org/10.36930/40300202 
присадибної ділянки території міста.

Предметом дослідження є методи і засоби благоустрою та озеленення присадибної ділянки міста Умань, що дасть змогу підвищити естетичність, декоративність та функціональність відповідної території.

Метою дослідження є розроблення проекту благоустрою та озеленення присадибної ділянки для підвищення естетичності, декоративності та функціональності цієї території.

Завдання дослідження полягають в такому: зробити комплексний аналіз об'єкта озеленення; проаналізувати наявні насадження на цій території; зробити проектні пропозиції щодо озеленення та благоустрою території; запропонувати асортимент рослин для естетичного оформлення ділянки; скласти проект озеленення.

Наукова новизна роботи полягає у тому, що було вперше розроблено проект благоустрою та озеленення присадибної ділянки для підвищення іiі естетичності, декоративності та функціональності.

Практична значущість отриманих результатів полягає у тому, що на зазначеній ділянці міської території рослини підібрано так, що додано унікальності цьому об'єкту, підкреслено кожну запропоновану зону, але водночас збережено цілісність загальної задумки та композиції всієї місцевості.

Методи дослідження - біоекологічні, дендрологічні, методи ландшафтної графіки.

Результати дослідження. Об'єкт озеленення розташований у місті Умань Черкаської області в регіоні 3 помірно-континентальним, м'яким кліматом 3 порівняно теплою зимою і частими відлигами. Найбільша кількість опадів припадає на літній період - 37,7 \%. Панівні напрями вітру - західний і північно-західний. Середня швидкість вітру становить 3-8 м/с. Грунти на присадибній ділянці представлені чорноземами із $\mathrm{pH}$ 5,5-6,0. Знання природо-кліматичних особливостей регіону допоможуть у правильному підборі рослинності та створенні для неї сприятливих умов.

Присадибна ділянка загальною площею $2725,8 \mathrm{~m}^{2}$, має прямокутну форму та рівнинний рельєф. Дорожньо-стежкова мережа влаштована та вписується в загально-планувальну композицію об'єкта. 3 рослинності ростуть туя західна (Thuja occidentalis 'Smaragd') 147 шт., сосна гірська (Pinus mugo) - 1 шт., ялина звичайна (Picea abries 'Little Gem') - 2 шт. та ялівець лускатий (Juniperus squamata 'Blue Carpet') - 1 шт.

Таблиця. Баланс території ділянки

\begin{tabular}{|l|c|c|}
\hline \multicolumn{1}{|c|}{ Найменування території } & Площа, $^{2}$ & Примітка \\
\hline Дорожньо-стежкове покриття & 798,3 & наявне \\
\hline Підпірні стінки (підвищення) & 322,0 & наявні \\
\hline Бесідка & 47,0 & наявна \\
\hline Гараж з накриттям & 97,2 & наявний \\
\hline Санвузол & 3,5 & наявний \\
\hline Будинок & 180,9 & наявний \\
\hline Водойма & 18,6 & наявна \\
\hline Садові меблі & 9,9 & проектується \\
\hline Фонтани & 1,0 & проектується \\
\hline Озеленення & 795,9 & наявне/проек- \\
тується \\
\hline Декоративна кора & 289,9 & проектується \\
\hline Декоративний гравій & 161,6 & проектується \\
\hline Загальна площа & 2725,8 & наявна \\
\hline
\end{tabular}

Присадибну ділянку поділено на зони: вхідна частина, де праворуч від воріт, розміщений цегляний гараж 3 навісом і партерна, представлена підпірними стінками 3 обох сторін дорожньо-стежкового покриття. Будинок розташований між партерною зоною та зоною відпочинку із водоймою, бесідкою та санвузлом. 3 обох боків будинку, починаючи 3 воріт і до кінця ділянки вздовж паркану, висаджені Th. occidentalis 'Smaragd', а біля водойми - Pinus mugo, Picea abries 'Little Gem' та Juniperus squamata 'Blue Carpet'. Баланс території проектованої ділянки наведено в таблиці.

Присадибна ділянка має бути місцем краси та спокою, де можна відпочити та налагодити гармонію 3 довкіллям. Метою її створення є функціональний і привабливий пейзаж. Кінцевим результатом під час створення ділянки є ії зручне обслуговування (рис. 1).

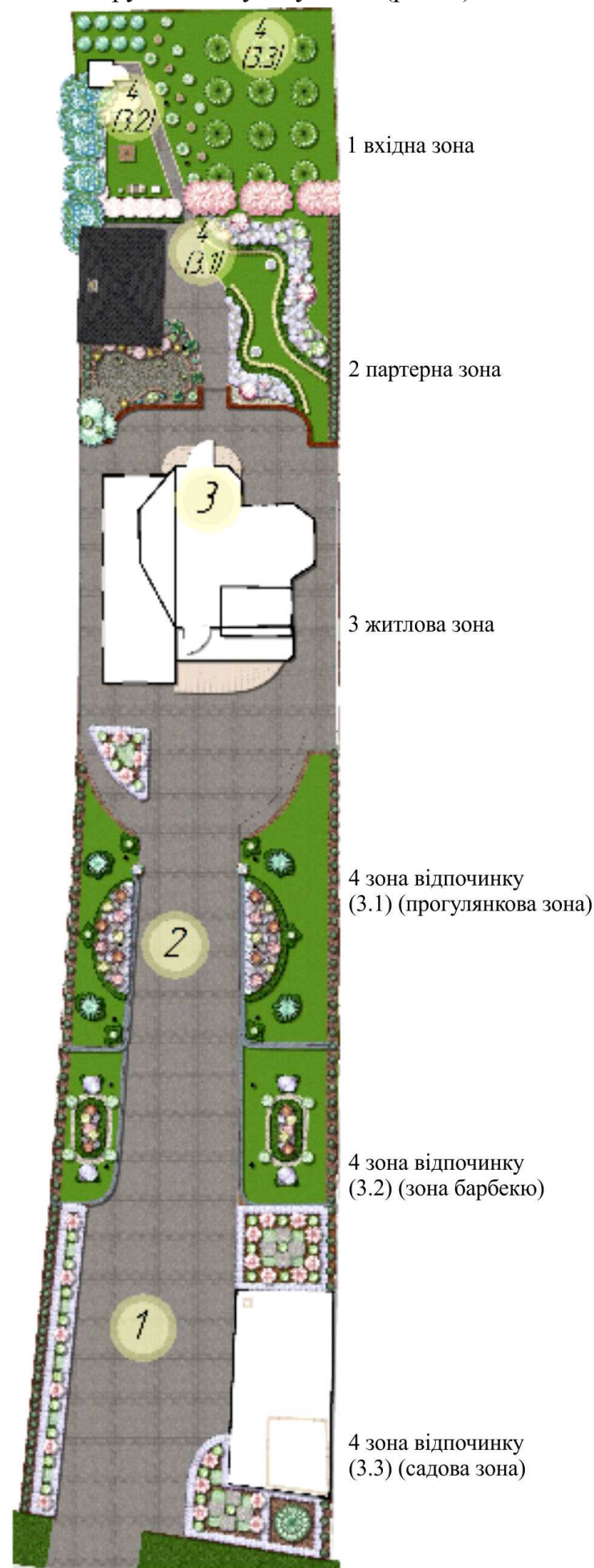

Рис. 1. Функціональне зонування території 
Функціональне зонування території - це поділ проектованого об'єкта на окремі сегменти (функціональні зони ділянки), що несуть конкретне функціональне навантаження, а також організація взаємних зв'язків цих зон для створення цілісної і раціональної планувальної композиції. Пропонуємо розділити територію присадибної ділянки на декілька функціональних зон (рис. 1):

1) вхідна зона - вхід на ділянку та в'їзд для автомобіля, гараж із навісом;

2) партерна зона - розташована перед будинком з відповідними рослинними композиціями;

3) житлова зона - житловий будинок і доріжки, що з'єднують і забезпечують доступний прохід;

4) зона відпочинку, яку поділяють на:

4.1) прогулянкову зону - представлену бесідкою, водоймою та рослинними композиціями $з$ фонтанами;

4.2) зону барбекю - споруди для барбекю, садові лави, що розташовані поруч з бесідкою;

4.3) садову зону - невеликий яблуневий сад з ягідними кущами позаду трельяжу.

Вхідна зона - вхід на ділянку та в'їзд для автомобі-

ля. Праворуч від воріт пропонуємо висадити бордюр 3 лаванди вузьколистої (Lavandula angustifolia L.) 65 шт., за ним - самшит вічнозелений (Buxus sempervirens L.) сформований у вигляді куль - 4 шт., що чергуються 3 гортензією крупнолистою (Hydrangea macrophylla 'Bodensee') - 3 шт., за ними пропонуємо розмістити бересклет Форчуна (Euonymus fortunei 'Emerald \& Gold') сформований у вигляді кубів - 60 шт. та чергуються 3 шавлією дібровною (Salvia 'May Knight')16 шт. У центрі цієї композиції передбачено висадити самшит вічнозелений (Buxus sempervirens), сформований у вигляді кулі - 1 шт., далі гортензію крупнолисту (Hydrangea macrophylla 'Bodensee') - 2 шт. і бордюр 3 лаванди вузьколистої (Lavandula angustifolia) - 38 шт. Акцентною рослиною $є$ нівакі (садовий бонсай) 3 ялівцю китайського (Juniperus chinensis 'Blue Alps') - 1 шт. Завершує композицію висаджена вздовж паркану туя західна (Thuja occidentalis 'Smaragd') - 4 шт. Цю ділянку пропонуємо замульчувати декоративною корою $50 \mathrm{~m}^{2}$, що допоможе досягти більшої гармонійності композиції та стане ефективним способом полегшення догляду за цією ділянкою (рис. 2).

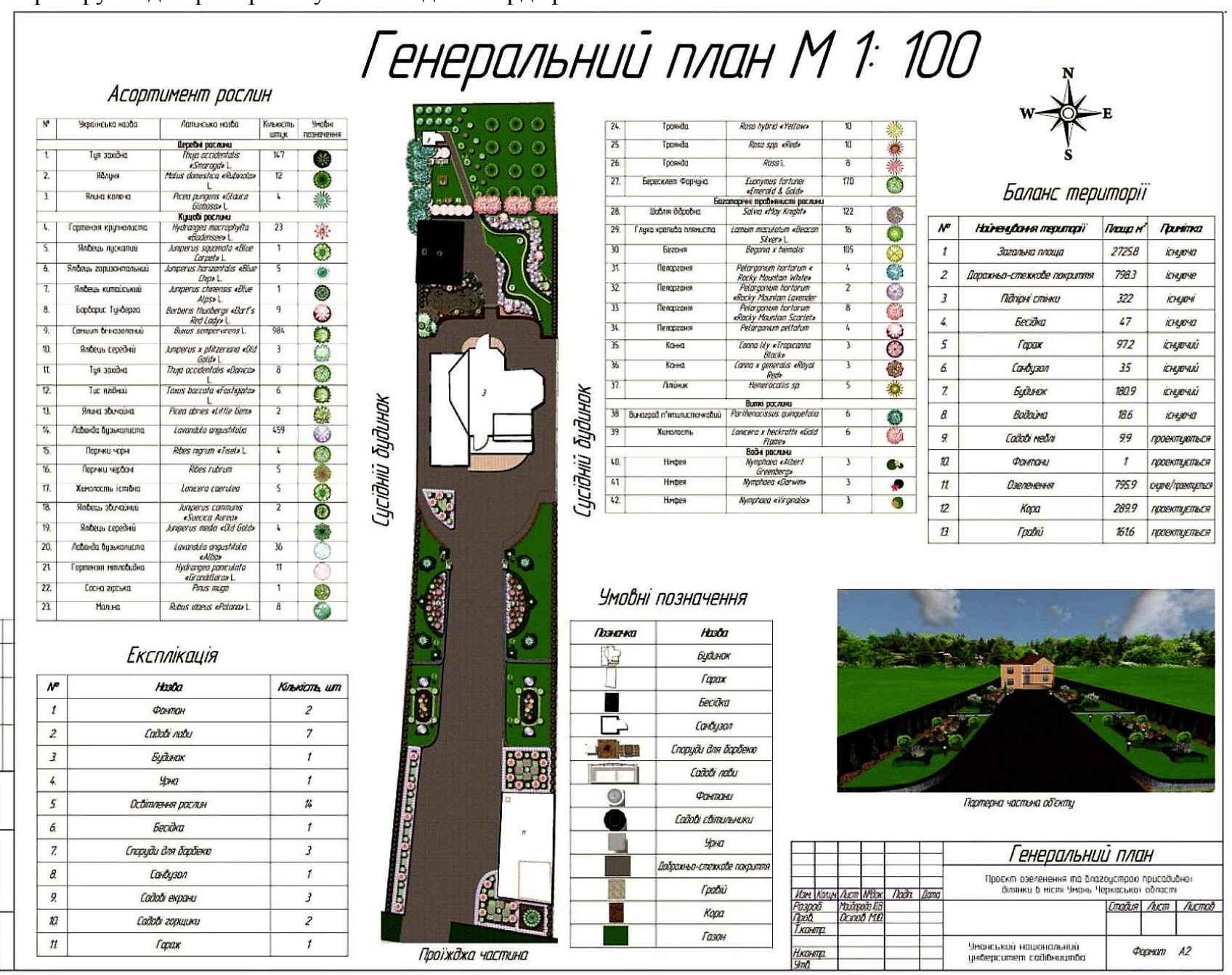

Рис. 2. Генеральний план присадибної ділянки, м. Умань

Гараж із накриттям, загальною площею 97,2 м², розташований праворуч від воріт. Ділянку квадратної форми ліворуч від гаража також пропонуємо замульчувати декоративною корою. Ділянка містить такі ж рослини, як і з правого боку гаража, за винятком ялівцю китайського.

Ліворуч від воріт пропонуємо також облаштувати бордюр 3 лаванди вузьколистої (Lavandula angustifo- lia) - 128 шт., на задньому фоні розмістити тую західну (Thuja occidentalis 'Smaragd') - 33 шт., у лаванді - підсадку 3 самшиту вічнозеленого (Buxus sempervirens) 10 шт., гортензії крупнолистої (Hydrangea macrophylla 'Bodensee') - 6 шт. і формованих рослин з бересклета Форчуна (Euonymus fortunei 'Emerald \& Gold') - 60 шт. Ділянку площею 54,5 м² передбачено замульчувати сосновою корою. 
Партерна зона розташована перед будинком 3 поділом на дві частини. Підпірні стінки виділяють і розділяють загальну площу, відведену під озеленення. Рослини цієї ділянки: бордюр із самшиту вічнозеленого (Buxus sempervirens) - 316 шт., вистрижений геометричними фігурами, де ростуть лаванда вузьколиста (Lavandula angustifolia) - 8 шт., шавлія дібровна (Salvia 'May Knight') - 8 шт.; у центральному овалі зі самшиту - троянди (Rosa hybrid 'Yellow') - 4 шт., (Rosa spp. 'Red') 4 шт., (Rosa L.) - 2 шт., лаванда вузьколиста (Lavandula angustifolia) - 6 шт., шавлія дібровна (Salvia 'May Knight') - 4 шт. 3 боків овалу з самшиту - туя західна (Thuja occidentalis 'Danica') - 8 шт.

Наступна частина партерної зони містить такі рослини: бордюр із самшиту вічнозеленого (Buxus sempervirens) - 318 шт. для виділення рослинних композицій завдяки різноманітним геометричним формам i контрасту з іншими рослинами. Всередині самшиту пропонуємо посадити симетрично по обидва боки обох частин партерної зони - тис ягідний (Taxus baccata 'Fastigiata') - 6 шт., вистрижений спірально по 3 штуки - 3 боків та посередині композиції. У центрі висаджений самшит вічнозелений півколом, а всередині ньоготроянди: Rosa hybrid 'Yellow' у кількості 6 шт., Rosa spp. 'Red'- 6 шт., Rosa - 6 шт., а також лаванда вузьколиста (Lavandula angustifolia) - 26 шт., Lavandula angustifolia 'Alba' - 12 шт., шавлія дібровна (Salvia 'May Knight') - 30 шт.

Між тисом ягідним та півколом із троянд пропонуємо висадити ялину колючу (Picea pungens 'Glauca Globosa') - 4 шт. на штамбі висотою 80 см. Цю ж рослину бажано висадити у геометричну форму зі самшиту вічнозеленого (Buxus sempervirens).

3 обох боків головної доріжки вмонтовані бетонні вази, де пропонуємо висадити пеларгонії: (Pelargonium hortorum 'Rocky Mountain White') - 4 шт., (Pelargonium hortorum 'Rocky Mountain Lavender') - 2 шт., (Pelargonium hortorum 'Rocky Mountain Scarlet') - 8 шт. та глуху кропиву плямисту (Lamium maculatum 'Beacon Silver') 16 шт.

Перед вхідними дверима до будинку невелику ділянку трикутної форми потрібно оздобити бордюром 3 лаванди вузьколистої (Lavandula angustifolia) - 39 шт., потім висадити гортензію крупнолисту (Hydrangea macrophylla 'Bodensee') - 4 шт., чергуючи 3 кульками самшиту вічнозеленого (Buxus sempervirens) - 4 шт., а в середині композиції, вистрижений у формі трикутника, бересклет Форчуна (Euonymus fortunei 'Emerald \& Gold') - 21 шт.

Газонне покриття єднає загальну композицію, а

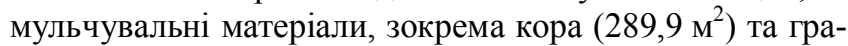
вій $\left(161,6\right.$ м $\left.^{2}\right)$, підкреслюють і виділяють рослинні композиції. Житлова зона - житловий будинок площею 180,9 м $^{2}$ д доріжками, що з'єднують та забезпечують доступний прохід. Цю зону поділено на дві частини: передню, що веде до партерної частини, та задню - для з'єднання із зоною відпочинку.

До будинку та навколо нього розміщується плиткова дорожньо-стежкова мережа, загальною площею 798,3 м², прокладена до кожної із наведених зон. Зону відпочинку поділено на: прогулянкову зону, садову зону, з водяних рослин, зону барбекю, садову зону.
Прогулянкова зона - це бесідка, водойма та рослинні композиції з фонтанами. Бесідка розташована між водоймою і зоною барбекю, що досить вигідно, адже в сонячну погоду відпочинком може слугувати спеціально відведена зона, а в дощову погоду чи дуже спекотну можна розміститися в бесідці і спостерігати за природою. Загальна площа бесідки становить $47 \mathrm{~m}^{2}$.

Перед бесідкою пропонуємо створити композицію із хвилястих ліній самшиту вічнозеленого (Buxus sempervirens) - 211 шт., бордюру з бегонії (Begonia x hiemalis) - 105 шт. і кульок різних розмірів із самшиту (Buxus sempervirens) - 6 шт. та барбарису Тунберга (Berberis thunbergii 'Dart's Red Lady') - 9 шт. Також дана композиція містить такі рослини як: шавлія дібровна (Salvia 'May Knight' L.) - 48 шт. та лаванда вузьколиста фіолетового й білого кольору (Lavandula angustifolia 'Alba') 23 шт., (Lavandula angustifolia) - 74 шт. Між композиціями заплановано розмістити газонне покриття та два фонтани загальною площею $1 \mathrm{~m}^{2}$, що доповнюють загальний задум. На площі, де висаджені декоративні композиції, $\epsilon$ мульчувальний матеріал - гравій загальною площею 161,6 м². На задньому фоні передбачено влаштувати рядова посадку з туї західної (Thuja осcidentalis 'Smaragd') - 33 шт.

Садову зону з прогулянковою розділяє три трельяжі 3 дерева для опори жимолості (Lonicera $x$ heckrottii 'Gold Flame') - 6 шт. Його функція - розмежувати дві зони та створити фон для прогулянкової зони.

Водойма розміщена праворуч від бесідки і має загальну площу 18,6 м² $^{2}$ За водоспадом пропонуємо посадити ялівець звичайний (Juniperus communis 'Suecica Aurea') - 2 шт., ялівець середній (Juniperus x pfitzeriana 'Old Gold') - 3 шт. Навколо водойми можна розмістити такі рослини: ялівець горизонтальний (Juniperus horizontalis 'Blue Chip') - 5 шт., туя західна (Thuja occidentalis 'Smaragd')-5 шт., канна (Canna lily 'Tropicanna Black') - 3 шт., канна (Canna $x$ generalis 'Royal Red') 3 шт., лілійник (Hemerocallis) - 5 шт., ялина звичайна (Picea abries 'Little Gem') - 2 шт., ялівець середній (Juniperus media 'Old Gold') - 4 шт., ялівець лускатий (Juniperus squamata 'Blue Carpet') - 1 шт., ялівець горизонтальний (Juniperus horizontalis 'Blue Chip') - 5 шт.

3 водяних рослин - німфеї: (Nymphaea 'Albert Greenberg') - 3 шт., (Nymphaea 'Darwin') - 3 шт., (Nymphaea 'Virginalis') - 3 шт.

Зона барбекю представлена досить компактно розміщеними спорудами для барбекю: мангал, садова піч, стіл для приготування їжі, садові лави для відпочинку. Позаду цих споруд пропонуємо висадити гортензії мітловидні (Hydrangea paniculata 'Grandiflora') - 11 шт. і бордюр з самшиту вічнозеленого (Buxus sempervirens) 105 шт. Попід парканом - виноград дівочий п'ятилисточковий (Parthenocissus quinquefolia L.) - 6 шт., який буде досить ефектно виглядати в літній та осінній періоди і створюватиме загальний фон для гортензій.

Садова зона - невеликий яблуневий сад, де пропонуємо висадити дерева яблуні домашньої (Malus domestica 'Rubinola') - 12 шт., що зростатимуть позаду трельяжу, та ягідні кущі, зокрема: чорна смородина (Ribes nigrum 'Tisel') - 4 шт., порічки червоні (Ribes rubrum L.) - 5 шт., жимолость їстівна (Lonicera caerulea L.) - 5 шт. і малина (Rubus idaeus 'Polana') - 8 шт. 
Висновки. Внаслідок проведеного дослідження було розроблено проект благоустрою та озеленення присадибної ділянки міста Умань для підвищення естетичності, декоративності та функціональності цієї теритоpii. За результатами дослідження можна зробити такі основні висновки:

1. Ділянка перебуває в гарному стані, хоча потребує насичення рослинністю. На ділянці не проглядається загальний задум, тому пропонуємо розмістити наведені вище рослини відповідно до їх функціональних зон. Таким способом вдасться раціонально використати загальну площу з уже прокладеною дорожньо-стежковою мережею та створити зручне зонування для експлуатації всієї території.

2. Рослини підібрано так, щоб додати унікальності цьому об'єкту, підкреслити кожну запропоновану зону, але водночас зберегти цілісність загальної задумки та композиції всього об'єкта. Декоративність кожної рослини підкреслюється сезонно, тому мешканці цієї ділянки зможуть милуватися композиціями в будь-яку пору ро- ку. Вся територія з композиціями гарно освітлюється, чим підкреслюється фактура рослин та їх форми.

\section{References}

1. Astakhova, E. V., Krupa, T. N., \& Cherevatenko, M. G. (2007). Landshaftnyi dizain: sovremennye resheniia. Kh.-Belgorod: Knizhnyi klub "Klub Semeinogo Dosuga", 317 p. [In Russian].

2. Belochkina, Iu. V. (2006). Landshaftnyi dizain. Kharkiv: Folio, 317 p. [In Russian].

3. Kryzhanivska, N. Ya. (2009). Osnovy landshaftnoho dyzainu. Kyiv: Lira-K, 218 p. [In Ukrainian]

4. Kucheriavyi, V. P. (2005). Ozelenennia naselenykh mists. Lviv: Svit, 456 p. [In Ukrainian].

5. Osipov, M. Y., Velichko, Y. A., Maslovata, S. A., \& Kulbitskyi, V. L. (2019). Proekt rekonstruktsii Shakhtarskoho bulvaru v misti Vuhledar Donetskoi oblasti. Scientific Bulletin of UNFU, 29(6), 49-53. https://doi.org/10.15421/40290610

6. Varlashchenko, L., Polishchuk, V., \& Velychko, Y. (2017). Vykorystannia vytkykh roslyn dlia vertykalnoho ozelenennia umanskoho natsionalnoho universytetu sadivnytstva. Scientific Bulletin of UNFU, 27(4), 28-31. https://doi.org/10.15421/40270405

G. P. Leontiak', M. Yu. Osipov'2, S. A. Maslovata 2 , Yu. V. Mauboroda'

${ }^{1}$ Vinnytsia National Agrarian University, Vinnytsia, Ukraine

${ }^{2}$ Uman National University of Horticulture, Uman, Ukraine

\section{LANDSCAPING AND IMPROVEMENT PROJECT FOR A GARDEN PLOT IN THE CITY OF UMAN}

Landscaping is an integral part of the overall package of measures in the urban development, aimed at planning, building and improvement of populated places. Landscaping has a positive impact on the environment and the life of population in general. Green spaces are the main elements of artistic decoration of settlements, the aesthetic and emotional significance of which is due to their ability to alternate impressions of the environment, to introduce natural elements into the urban environment. An important component of the landscaping system is planting in residential areas that create favorable conditions for work and leisure. Of great importance is the principle of rationality in the placement of trees, shrubs and flower beds, their correct selection in accordance with the natural conditions, as well the garden and other green spaces care. Under a good location and good care combined with an efficient landscaping, the green spaces determine the ecological status of the settlements, as they are largely dependent on the microclimate and the natural purification of air, water and soil. In the process of pre-project studies, it was established that the plot has a rectangular shape and plain terrain, pathway network, a pergola, a pond, a house, a garage and a WC. The area of the landscaping object is $2725,8 \mathrm{~m}^{2}$. All the structures are in good condition. The pathway network and architectural concept are aimed to design the plot in a regular style. Creation of the landscape gardening object, taking into account the peculiarities of the climatic conditions, customer wishes and functional zoning will give the territory a complete look and will serve as a recreation area for the whole family. The plot is in good condition, though it requires saturation of vegetation. The plot does not show the overall design, so it is proposed to place the above plants in accordance with their functional zones. This will allow to rationally use the total area with the already laid pathway network and to create a convenient zoning for the operation of the whole territory. Plants are chosen to add uniqueness to this object, emphasize each proposed area, but at the same time preserve the integrity of the general design and composition of the whole object. The decorative nature of each plant is emphasized seasonally, so the residents of this plot will be able to admire the compositions at any time of the year. The whole territory with the compositions is well lit, which emphasizes the texture of the plants and their forms.

Keywords: landscape gardening; site plan; functional zones of territory; residential area; recreation area; landscaping; improvement. 